\title{
Sobre os poetas neo-realistas. Exercícios de releitura: poéticas do testemunho e gesto antropológico
}

\author{
About the neo-realist poets. Rereading exercises: \\ poetries of testimony and anthropological gesture
}

Manuel Gusmão

Centro de Estudos Comparatistas, Faculdade de Letras, Universidade de Lisboa, Lisboa / Portugal

mgusmao@netcabo.pt

Resumo: Os autores neo-realistas distinguem-se pela prática da literatura como testemunho e gesto antropológico, patente não apenas na prosa mas igualmente na poesia. É essa a linha condutora destes exercícios de leitura da poesia de Manuel da Fonseca, Mário Dionísio, Joaquim Namorado, Carlos de Oliveira e de Gaibéus de Alves Redol.

Palavras-chave: Poesia e testemunho; literatura e gesto antropológico; neo-realismo e modernismo.

Abstract: Neo-realist authors are defined by the practice of literature as testimony and anthropological gesture. We can find it not only in their prose but also in their poetry. This topic is the guiding line of these exercises of reading the poetry of Manuel da Fonseca, Mário Dionísio, Joaquim Namorado, Carlos de Oliveira and of Gaibéus de Alves Redol. Keywords: Poetry and testimony; Literature and anthropological gesture; Neo-realism and modernism.

Recebido em 23 de março de 2017 Aprovado 4 de maio de 2017 
Os escritores neo-realistas portugueses estão ligados a uma concepção e a uma prática da literatura como testemunho e gesto antropológico. Curiosamente esses dois traços encontramo-los desde as primeiras obras de um autor que não se pode considerar tecnicamente um poeta: Alves Redol. Por outro lado, a caracterização desta ligação dos neo-realistas só é compreensível quando chamada a cumprir uma estratégia de releitura.

Redol publica o seu primeiro livro, Glória, uma aldeia do Ribatejo, que o seu autor considera, em título, ser um ensaio etnográfico e, só depois, um romance que traz uma epígrafe que diz assim: "Este romance não pretende ficar na literatura como obra de arte. Quer ser, antes de tudo, um documentário humano fixado no Ribatejo".

O neo-realismo literário começa em 1939 com Gaibéus de Alves Redol e com Rosa dos Ventos, em 1940, de Manuel da Fonseca. Em Gaibéus, desde o texto escrito pelo seu autor para a edição de 1965 , que ocupa o lugar de uma espécie de posfácio de autor e passará a ser, a partir daí, o primeiro capítulo da obra, fica clara a intenção antropológica na qual o romance mergulha, quer ao nível da sua estrutura narrativa fundamental, quer ao nível dos princípios estruturantes da sucessão das frases.

Vejamos como ele se constrói, na malha das frases do texto, e supõe a plasticidade narrativa, o equilíbrio na distribuição das massas sintácticas.

No capítulo "Mensagem da Nuvem Negra" (REDOL, 1993, p. 157-204), encontramos a intervenção de um processo de repetição, que designaremos como estribilho levado a um extremo que dá conta de uma contaminação da prosa por procedimentos da poesia.

"-Auga!... Auga!...", que se repete três vezes a intervalos muito curtos (REDOL, 1993, p. 160-161), reaparece mais duas vezes agora a intervalos sensivelmente mais largos e cruzando-se com outras fórmulas que se repetem (REDOL, 1993, p.175-176). Esta teia que combina séries de elementos e variantes expõe uma complexa malha de tessitura verbal e de interacções entre os elementos humanos e naturais.

$$
\begin{aligned}
& \text { “- Eh, gente!...” (p. 161) } \\
& \text { “A ceifa não pára - a ceifa não pára nunca.” (p. 162) } \\
& \text { “A ceifa corre lenta. Dolorosa e lenta.” (p. 163) }
\end{aligned}
$$


"E a ceifa não pára - a ceifa não pára nunca.” (p. 163)

"Mas a ceifa corre lenta. Dolorosa e lenta." (p. 163)

"Eh, gente!..." (p.163)

"Nem para ela nem para os seus companheiros a ceifa pode parar -a ceifa é o pão." (p. 164)

“A ceifa não pode parar - a ceifa é o pão.” (p. 164)

“-Auga!... Auga!...” (p. 164)

“-Eh gente!...” (p. 172)

"Era preciso mais pressa [...].” (p. 172)

“-Vá, gente!... Eh, gente!” (p. 172)

“-Eh, gente!... Vá, gente!” (p. 172)

"Era preciso mais pressa - cada vez mais pressa." (p. 172)

“-Vá, gente!... Eh, gente!...” (p. 173)

“-Eh, gente!... Vá, gente!...” (p. 173)

"Era preciso mais pressa - cada vez mais pressa." (p. 173)

“A ceifa não pára - a ceifa não pára nunca.” (p. 173)

“-Vá, gente!... Eh, gente!...” (p. 174)

"Era preciso mais pressa - cada vez mais pressa.” (p. 174)

“-Vá, gente!... Eh, gente!...” (p. 174)

“-Vá, gente!... Eh, gente!...” (p. 174)

"Era preciso mais pressa cada vez mais pressa.” (p. 174)

“-Eh, gente!... Vá, gente!...” (p. 174)

"Era preciso mais pressa - cada vez mais pressa, sempre mais.// Mais depressa ainda." (p. 175)

“-Eh, gente!... Vá, gente!” (p. 175)

“-Auga!... Auga!...” (p. 176)

"[...] é preciso mais pressa - cada vez mais pressa - sempre mais." (p. 176) 
“As foices iriam parar e a ceifa era o pão.” (p. 176)

"E é preciso mais pressa - cada vez mais pressa." (p. 177)

“A ceifa é o pão - e as foices vão parar.” (p. 177)

$[\ldots]$

“O negrume do céu era mensagem de fome. A angústia dos ceifeiros, o seu espectro." (p. 186)

"Mas a mancha negra queria alastrar por todo o céu e já chegara até eles, tornando-os sombrios." (p. 186)

"Quem mandava ali não era o Francisco Descalço, mas a mancha negra que assolapava todo o norte. $O$ capataz estava assim porque o patrão lhe levara a Rosa. Se não fosse a mensagem da mancha negra, eles sorririam dos seus ralhos." (p. 187)

"Vinha com eles a noite da mancha negra que lhes trazia mensagem. $E$ a mensagem dizia-lhes que a ceia não se ganhava." (p. 187)

“[...] a ceifa trocava-se por pão.” (p. 187)

Alguns ficaram confiando na mancha negra, confiando na mancha negra $[\ldots] . "($ p. 187)

“[...] e só a mancha negra cantava.” (p. 188)

"E são muitos pingos - e são muitos sons. Uma orquestração que traz a mensagem da mancha negra." (p. 188)

"A chuva lembra aos ceifeiros que a ceia não foi ganha. A ceifa parou - e a ceifa é o pão.” (p. 195)

"A empreitada não dá a ceia - ceia de água com massa cortada e feijões." (p. 204)

“A empreitada não dá a ceia." (p. 204) Gaibéus.

Por outro lado, a epígrafe abre para uma breve memória de

O romance neo-realista cumpre além disso uma função que ele próprio reivindicou para si: uma função testemunhal. É sobre essa função que o texto "Breve memória", escrito por Alves Redol para acompanhar as edições de Gaibéus, a partir de 1965, se debruça. E o seu movimento final começa assim: 
Gaibéus tem a sua história. [...]

Gaibéus nasceu quando muitos morriam por nós. Não os esqueçamos. Seria absurdo, mesmo no mundo paradoxal, olvidar o que a esses devemos. Impõe-se recordar certas datas:

Em Março de 1938 as tropas hitlerianas entravam na Áustria;

Em Setembro ocupavam o território dos Sudetas e conseguiam a paralisia estratégica da Checoslováquia;

Em Março de 1939, ainda sem combate, o nazismo ocupava o resto daquele país;

Em Setembro de 1939 penetrava na Polónia.

Seguiu-se a segunda grande guerra, que deixou no rasto do seu apocalipse 55 milhões de mortos e 5 milhões de desaparecidos.

Pressentiram-na desde 1936 muitos homens desse tempo. Eu estava com eles. Gaibéus germinou nessa época e foi consciência alertada antes de ser romance. Quem o ler, portanto, deve ligá-lo às coordenadas da história de então. Só dessa forma saberá lê-lo na integra.

Penso que fora do contexto social do lugar e do tempo, não há obras literária que se compreenda na raiz. Há excepções, sem dúvida, e muito honrosas. Mas esta, pelo menos, nunca se libertará, e ainda bem, da hora trágica e consciente que a viu nascer.

Maio de 1965.

Alves Redol

É imperioso avaliar a verdadeira espessura das trevas que se abatiam sobre Portugal, a Península Ibérica, a Europa e o mundo, para se poder compreender o ethos e o tipo de energueia que alimentam e iluminam as po-éticas neo-realistas. Em Portugal, as forças políticas que tinham vencido a 28 de Maio de 1926, combatem agora entre si pela exacta configuração do regime a construir. Será uma orientação autoritária, anti-parlamentar, anti-operária e anti-comunista que triunfará e virá a definir o regime fascista em Portugal. A Constituição de 1933 é aprovada por plebiscito. A reorganização da Censura Prévia (a 11 de Abril de 1933); a criação da Polícia de Vigilância e Defesa do Estado (PVDE) (a 29 de Agosto); a Legislação básica da organização corporativa (a 23 de Setembro); a criação do Secretariado da Propaganda Nacional (a 25 de Novembro) são peças fundamentais desse processo de fascização do regime. 
Os trabalhadores respondem com as tentativas de reagrupar as suas forças, as lutas pelo pão e contra o desemprego. A 1 de Janeiro de 1934, entra em vigor o Estatuto do Trabalho Nacional, que tinha por modelo a "Carta del Lavoro" de Mussolini. Decretava-se a ilegalização dos Sindicatos. A "greve geral insurrecional" de 18 de Janeiro de 1934 (greve e tentativa de insurreição na Marinha Grande e em outros lugares, na cintura industrial de Lisboa) falha. A repressão desencadeia-se sobre o movimento operário, sobre anarco-sindicalistas e comunistas.

A repressão e a derrota das conspirações reviralhistas desmantelam o que restava das correntes anarco-sindicalistas e do socialismo reformista. Entretanto, a partir do 18 de Janeiro de 1934, será o PCP a única organização operária e antifascista que continuará no terreno (o PSP autodissolve-se em 1935) e que, a partir da reorganização de 40-41, se tornará a força hegemónica do movimento operário e a mais consequente organizadora e mobilizadora da oposição democrática e antifascista.

Esta nova preponderância político-organizativa dos comunistas, quer no movimento operário quer no campo oposicionista em geral, [...], mesmo quando na esteira político-táctica do republicanismo, fará do PCP um centro ideológico e organizativo incontornável da resistência ao regime. (ROSAS, 1994, p. 209).

Foi um combate social e político que se travou. Que atrás de si deixou um rasto de milhares de vítimas: mortos em combate, nas cadeias ou na tortura, deportados para as ilhas e as colónias; exilados e expulsos do país; presos nas cadeias e nos campos de concentração do continente, das ilhas e das colónias, para não falar das vagas de saneados da função pública (civil e militar) por motivos políticos. (ROSAS, 1994, p. 209).

Já na segunda metade da década de 30, as inteligências emocionam-se e as emoções incendeiam-se com a subida ao poder por via eleitoral de uma coligação de Frente Popular; a sublevação de Franco e o desencadear da guerra civil espanhola. A proximidade do cenário de guerra, o apoio de Salazar, como dos fascistas italianos e dos nazis alemães exasperavam a atenção com que os antifascistas portugueses seguiam os acontecimentos; a esperança e o desespero combatiam-se, intensamente, sem fim definitivo à vista. No horizonte pressentia-se o apocalipse da próxima conflagração mundial. A formação política e 
ideológica das novas gerações era neste cenário que se processava. Se algo se tornava claro por entre o nevoeiro que se adensava, é que era preciso tomar partido: tomar partido pela paz, pela liberdade, pelo pão, pelos trabalhadores.

A Guerra Civil espanhola, que começara em 1936, terminará, para deflagrar a II Guerra Mundial. Esta nova guerra em que Portugal terá uma equívoca participação, não «participante», aparece aos vencidos da tragédia espanhola, como uma nova versão da sangrenta guerra civil, só que agora travando-se à escala mundial. Esta ligação entre os dois conflitos vivida pela juventude de então como um elemento fundamental da subjectivação perceptiva dos acontecimentos é ela própria uma característica fundamental do modo como estes tempos são habitados pelo tipo de testemunhas que vão ser os neo-realistas portugueses. A percepção do perigo que ameaça as democracias e a própria humanidade é agravada pela derrota sofrida e pela sensação de impotência: é uma guerra a que se assiste, sem que nela se combata, a não ser na cabeça e no coração de cada um.

A tese VI de "Sobre o conceito da História" de Walter Benjamin dará directa e indirectamente conta do ambiente intelectual e passional desses tempos:

Articular historicamente o passado não significa reconhecê-lo «tal como ele foi». Significa apoderarmo-nos de uma recordação (Erinnerung) quando ela surge como um clarão num momento de perigo. Ao materialismo histórico interessa-lhe fixar uma imagem do passado tal como ela surge, inesperadamente, ao sujeito histórico no momento do perigo. O perigo ameaça tanto o corpo da tradição como aqueles que a recebem. [...] Só terá o dom de atiçar no passado a centelha da esperança aquele historiador que tiver apreendido isto: nem os mortos estarão seguros se o inimigo vencer. E este inimigo nunca deixou de vencer. (BENJAMIN, 2010, p. 11)

Neste ambiente, a tensão gera também um entusiasmo entre aqueles que vêem na cena em que participam uma arena onde se combate pela construção de um destino livre. O entusiasmo é, além do mais, uma característica geracional que é preciso imaginar se quisermos compreender a combatividade e mesmo o ânimo guerreiro desses jovens que formam a guarda avançada da geração neo-realista que começa por abrir o seu espaço e criar o seu lugar nas páginas de uma série de jornais 
e revistas, mais ou menos efémeras: O Diabo, Sol Nascente, Altitude, Pensamento, Seara Nova e Vértice, entre outros títulos. Este entusiasmo articulava, sob a sensação de perigo iminente, a paixão histórica e a urgência política. Estes jovens ardiam na tensão de unirem os seus ideais revolucionários em tempos de escuridão, a sua dedicação a um povo perante o qual se sentiam como representantes responsáveis e os seus projectos de emancipação cultural, a sua vontade de criarem beleza e de a partilharem como quem partilha o pão, a liberdade, o conhecimento.

Claro que estas paixões geram também equívocos e desacertos; quem escolhe reinventar caminhos ainda desconhecidos, senão mesmo insuspeitados, pode perder-se, ser seduzido por solicitações que desviam do caminho ou cair em emboscadas. ${ }^{1} \mathrm{O}$ que se censura como ingenuidade inábil ou como tenebrosa ignorância, é tantas vezes, mais do que um erro lógico formal, um efeito indesejado da generosidade.

$* * *$

A página final de Breve memória alinha rapidamente algumas datas referidas a esse apocalipse de meados do século XX.

Admitamos alguma perplexidade. Em que é que a história ou histórias contadas em Gaibéus pode proporcionar algum esclarecimento sobre aqueles efeitos que parecem implicar a história humana numa completamente outra escala de valores e proporções? Repetindo de certa forma a pergunta, mas procurando formular à partida as eventuais dificuldades que ela levanta: como pode admitir-se que testemunhar de algo acontecido no quadro de uma migração sazonal de trabalhadores entre duas regiões próximas de um pequeno país pode relacionar-se com a experiência da grande Carnificina? O que têm a ver histórias extraídas, de uma migração sazonal de gaibéus até à borda d'água com as datas da

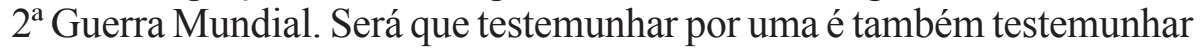
pela outra? Qual é o povo que está pelo outro?

Logo apareceram os primeiros ceifeiros, a passo estugado. $\mathrm{O}$ grupo cindiu-se. Uns continuaram a marcha, carril adiante, afeitos ao ambiente daquela emposta, em granjeios e segas; outros ficaram-se a mover a cabeça e a olhar à volta, estranhos à imensidão da Lezíria,

\footnotetext{
${ }^{1}$ Distribuo pela frase os dois substantivos do título de um livro de poemas de Mário Dionísio, Solicitações e emboscadas, Coimbra, Atlântida, 1945.
} 
que se desdobra até ao infinito, numa chã retalhada por pastagens, poisios e searas.

Aos novatos parecia afoito o caminho dos companheiros, como se andassem por terras suas. Viram-nos saudar com o braço aquele desalmado seco e alto que estava no meio da lavra, arremedo de espantalho para afugentar pardais, e seguirem sempre à rabeira do singel.

Ainda bem que vinham outros lá atrás; iriam com esses. Fez-se um riacho de gente pelo carril adiante.

Para além, o mesmo plaino onde só os aposentos e os palheiros eram tropeço à vista. Uma ou outra árvore, espalhada pela borda das abertas, lembrava as frondes das suas terras distantes.

Subidos em estertores, quase desfolhados já e amarelecidos, aqueles troncos não eram gritos vivos de seiva - assemelhavam-se a figuras humanas que o desalento tocara.

Nem sequer a alvura de uma aldeia ou os seios de um monte.

Para o sul só planície e céu-céu e planície. (REDOL, 1993, p. 59-60).

E eis que surge a primeira nota a ser repetida, no capítulo seguinte, uma segunda vez:

Mas aqui ...

Só planície e céu - céu e planície. (REDOL, 1993, p. 69, 292)

Deste protagonista colectivo destacam-se algumas personagens que atingem um grau de individualização que é esclarecedor do ethos da narrativa. São personagens que são providos de um Nome Próprio ou mesmo do que podemos designar como um epíteto épico.

São as cenas de trabalho que melhor suportam e dão a ler a inscrição dos movimentos do protagonista colectivo. É nelas que encontramos uma forma de construção narrativa que nos remete para uma percepção objectiva, quer da paisagem física quer da estrutura mental e cognitiva que configura a cena.

Assim, na cena contada no segundo capítulo, a percepção colectiva apresenta dois estribilhos diferenciados: um refere a necessidade da ceifa seguir adiante, o outro oferece uma justificação para essa pressa.

A ceifa, porém, vai sempre adiante - sempre adiante que lá em baixo, no aposento, o patrão está a fazer contas à colheita, que correu de boa maré. (p. 80) 
Anda-lhes nos pulsos uma moinha que pede descanso, mas o trabalho não pode parar.

Não pode parar porque lá em baixo, no aposento, o patrão está a fazer contas à colheita, que coreu em boa maré. (REDOL, 1993, p. 83)

E ainda algumas páginas depois:

A ceifa vai sempre adiante - sempre adiante, porque lá em baixo, no aposento, o Agostinho Serra está a fazer contas ao que colhe e ao que paga ao pessoal e à Companhia. (REDOL, 1993, p. 95)

$\mathrm{Na}$ ordem da percepção sensorial da ceifa, por exemplo, o texto anota a policromia: "havia agora laivos sanguíneos que depois eram roxos. //Roxos e amarelos... Sanguíneos e azuis... [...] Parecia até que os cabelos se tornavam roxos. [...] Roxos e azuis... Sanguíneos e amarelos." (REDOL, 1993, p. 81-83).

É neste quadro que a abundante transcrição de versos das canções que os ceifeiros entoam se torna mais uma marca da objectividade épica ou da pertença a um mesmo colectivo social ou étnico.

$\mathrm{Na}$ segunda cena de trabalho, ou seja, numa cena que se centra no contar de uma intensa jornada de trabalho, o papel do estribilho na determinação da função construtiva da narrativa é magnificamente exibido.

Observe-se primeiro que os estribilhos formam uma rede de repetições irregularmente sustentadas. Quase no princípio do capítulo "Mensagem da nuvem negra", pouco mais de uma página pode conter as ocorrências de três estribilhos diferentes.

O estribilho é um procedimento arquitectónico mais conhecido pela sua utilização na poesia lírico-narrativa. Ele torna visível a estrutura da história contada por tornar mais evidente a maneira de contar e tornase assim um procedimento que documenta a transição do poema ou da canção do romanceiro para a narrativa em prosa. No caso específico de Gaibéus, o estribilho é, pela sua agilidade de fórmula, com as suas variantes sintácticas, - a facilidade com que vários estribilhos se podem cruzar; pela sua relação como o corpo do texto em que surge, e pelo seu papel na construção do protagonista colectivo, uma marca épica, ou mais precisamente desempenha uma função de marca da objectividade épica. 


\section{Manuel da Fonseca}

Rosa dos ventos (1940), o primeiro livro de poemas de Manuel da Fonseca e o que convencionadamente inaugura a poesia neo-realista como Gaibéus de Alves Redol (1939) o faz para o romance, é um muito curioso livro. Vale a pena reparar em algumas das suas características, até para estabelecermos a comparação com o seu segundo livro de poemas, Planície:

$$
\begin{aligned}
& \text { - "Sete canções da vida" } \\
& \text { - "Canções da beira-mar" } \\
& \text { - "O Vagabundo e outros motivos alentejanos" } \\
& \text { - "Poemas da Infância" } \\
& \text { - "Poemas (Primeira parte) } \\
& \text { - "Poemas (Segunda parte) }
\end{aligned}
$$

Esta sua obra de estreia mostra já o gosto de Manuel da Fonseca pela organização em sequências de poemas, cujo título mostra a sua consistência temática e a sua unidade de inspiração. E é curioso reparar que se apenas o título da terceira sequência explicita a referência ao Alentejo, não deixa de se estabelecer uma relação semi-escondida entre poemas dessa sequência e o tema da segunda: o mar.

Embora o Alentejo tenha efectivamente uma relativamente razoável linha de costa marítima, acontece que aquele que nestes poemas se encontra em construção poética é um Alentejo interior.

Assim, a primeira das "Canções da beira-Mar" tem a abrir a terceira estrofe o seguinte verso: “... Ora veio um moço do interior e viu o mar: ficou maravilhado!” (FONSECA, 1984, p. 55).

É do mar, dificilmente visível em qualquer ponto desse Alentejo interior, que se trata, no poema "Nocturno", o $4^{\circ}$ de "O Vagabundo e outros motivos alentejanos". Reparar-se-á que se o título da sequência fala em motivos alentejanos, esse poema inscreve repetidamente o tema do mar:

O Jacinto Baleizão, que foi a África,

Fala do mar à gente.

$[\ldots]$ 


\author{
Zé Cardo, tu já viste o mar? \\ Eu, não... \\ Ninguém tinha visto o mar. \\ Jacinto Baleizão diz que tem ondas, \\ ondas altas como um castelo. (p. 67)
}

Aonde é?

Diz que da estrada que vai para o Cercal

há um cabeço donde se vê... (p. 68)

O poema tem a geografia certa - é aliás uma geografia autobiograficamente radicada -, mas o que aqui está em processo de construção mítico-poética é uma região que, podendo ser ela própria um mar, é habitada por uma comunidade imaginária que vive essa separação do mar de uma forma geneticamente constitutiva. Comunidade que é indiciada pelo conjunto dos poemas que constituem a $3^{\mathrm{a}}$. sequência.

Essa comunidade imaginária é formada por várias personagens que povoam esses sete poemas: Jacinto Baleizão, Zé Cardo, Tóino, Zé Limão, que aparecem todos no poema Nocturno; Maria Campaniça; Rosa Charneca. Esta última surge nesse mesmo poema, também em "Canção" e ainda no poema que tem o seu nome por título, "Rosa charneca". E finalmente aquela personagem que vibra nos seus contornos, singular e aberta ao plural das figuras, a figura poético-mítica do maltês, ora cantando-se ou contando a sua própria história, na primeira pessoa (em "Vagabundo", "Canção de Maltez" e "Canção"), ora dirigindo-se a "Rosa Charneca", no poema que tem o nome dela.

$\mathrm{O}$ vagabundo ou o mendigo que surgem nos dois primeiros poemas da $3^{\mathrm{a}}$ sequência são figuras correlacionadas com as do "Vagabundo do mar".

O uso da primeira pessoa pela figura que se apresenta no poema gera uma inevitável ambivalência na determinação de quem é o sujeito que se enuncia no poema. É o poeta, que se diz na figura do vagabundo ou do maltês, ou são, na sua singularidade de figuras que dizem e mostram como são, o vagabundo e o maltês que reservam a alteridade do poeta que se retira para o fundo da cena.

E eis que surpreendentemente este livro de estreia de um poeta neo-realista nos apresenta uma estranha forma de monólogos dramáticos, forma poética que vive dessa confusão e diferenciação interna ao sujeito de enunciação. E que não a dá como experiência psicológica, mas como efeito de um modulação genológica, ou de uma tradição poética. 
O monólogo dramático pressupõe uma cena que o contextualiza. O poema "Canção" estabelece o guião, em que se virão inserir os dois monólogos que são "Rosa Charneca" e Canção de maltês". O drama tem assim uma apresentação narrativa, embora ela se resolva num dístico:

Num ano de grande fome,

Minha família acabou-se. (p. 69)

A segunda estrofe diz a condição feliz e estrutura-se em torno de um verso que se repete no seu interior - é o verso $8^{\circ}$ e o $10^{\circ}$ a contar do fim da estrofe, com cinco versos de intervalo entre essas duas ocorrências - a minha enxada luzia. Segue-se um novo dístico que diz o desastre:

Quando veio a grande fome tudo isto se acabou. (p.70)

E, então, a quarta estrofe distribui os destinos das personagens

Minha mulher foi prá monda, lá para o Alto Alentejo.

E a minha filha abalou com uma mulher que ri e anda de feira em feira armando aquela barraca Onde se bebe e se ama. E numa manhã de Inverno, Não pude mais e parti - pelas estradas do acaso com a manta de maltês!... (p. 70)

Os poemas que de imediato se seguem são de novo monólogos dramáticos. No primeiro, a personagem que se tornou maltês pergunta à filha ou aos ventos:

Rosa Charneca

Em que barraca da feira estás sorrindo?...

[...]

À noite

em que feira do Alentejo,

por ti, os malteses abrem as navalhas?... (p.71) 
Já o último poema não supõe necessariamente a ilusão de que ouvimos o mesmo maltês mas um qualquer outro deserdado.

Mas a construção do Alentejo não fica por aqui, ela confunde-se com a construção da infância, na sequência "Poemas da infância". E, coisa singular na poesia portuguesa, a imaginação da infância perdida recorda, em quatro dos cinco poemas, o despertar erótico, o grande mistério dos seios nascendo debaixo das blusas.

Neste primeiro livro de poesia, a rememoração dos lugares e dos espaços, e a experiência das diferentes durações lançam, de várias formas as suas raízes no imaginário do Alentejo e, dessa forma, disseminam a sua presença.

Como Fernando J. B. Martinho tem justamente insistido, também Pessoa e sobretudo Pessoa/Campos não foi indiferente aos neo-realistas, a Joaquim Namorado, por exemplo. Ora também por Manuel da Fonseca foi lido e nele deixou os seus vestígios. E, desde logo, em Rosa dos Ventos. Na "Sétima" das "Sete canções da vida", toma o mar como figura intensificadora da distância, do desejo de navegação, como metáfora do desejo de vida; embriaguez do marinheiro:

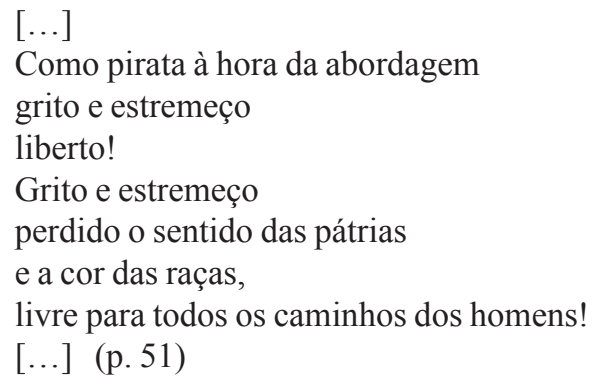

Podia ser um verso de Pessoa: "tudo em mim grita a ânsia da largada" (p. 52).

Em Planície (1941), o segundo livro de poemas de Manuel da Fonseca, já a construção mítico-poética do Alentejo percorre todo o livro, sem partilha. E não deixa de ser de realçar que é assim o segundo e não o primeiro livro que traz a apoteose dessa construção.

O livro organiza-se em três sequências de poemas, em que a $3^{\mathrm{a}}$ se apresenta claramente como um único poema, ou o esboço de um: "Para um poema a Florbela". 
O número das personagens aumenta, porque para além do aparecimento de algumas novas personagens retoma-se a invocação de outras que já conhecemos de Rosa dos ventos.

Personagens, pela ordem da sua entrada em cena: Nena de Montes Velhos; António de Valmorim; O senhor António; o terceiro oficial de Finanças da Câmara Municipal; Aquela menina casadoira; Francisco Charrua; Zé Gaio; o Julinho da ourivesaria; a Tuna do Zé Jacinto; Manuel da Água; a Marianita; Florbela; e Maria Campaniça.

Curioso traço deste fazer, que parece retomar em poesia aquela grande ilusão do romance realista do séc. XIX, para o qual a presença de uma mesma personagem em mais do que um romance era um gesto que pertencia à construção de um mundo literário que partilhava com o mundo real, pelo menos essa característica: ambos os mundos oferecem a possibilidade de encontrarmos em duas cenas diferentes uma mesma personagem. Esta comunidade imaginária que assim se constrói será como veremos uma comunidade clivada socialmente.

Mas comecemos de outra forma.

Pelo segundo poema da $1^{\mathrm{a}}$ sequência do livro; o poema "Aldeia":

Nove casas,

duas ruas,

ao meio das ruas

um largo,

ao meio do largo

um poço de água fria.

Tudo isto tão parado

e o céu tão baixo

que quando alguém grita para longe

um nome familiar

se assustam pombos bravos

e acordam ecos no descampado. (p. 111)

É um poema breve, formado por duas sextilhas. A primeira parece uma visão de cima que enumera casas e ruas num movimento que se prolonga, concêntrico. Um movimento que se cumpre só através de nomes e de preposições: das ruas para o seu centro - um largo e desse largo ainda para o seu centro, que se adentra na terra e oferece água, que estremece fria, com a vogal mais alta - i -, no único adjectivo e última palavra da estrofe. 
O primeiro dístico da segunda sextilha - Tudo isTo Tão parado/ e o céu Tão baixo - marcado pela aliteração da oclusiva surda, parece continuar o movimento de descrição de uma cena imobilizada. Mas não é bem isso que se vai passar. O Espaço cujo desenho está já terminado é o de uma caixa de ressonância, e a abertura de uma indefinida temporalidade que traz consigo um grito - quando alguém grita para longe - que vai fazer ressoar a paisagem da vila e do descampado que a rodeia.

Os últimos quatro versos alongam-se, passam a trazer consigo verbos, há agora frequentemente trissílabos e o grito vibra através da assonância das vogais nasais - quando alguém grita para longe se assustam pombos e acordam ecos no descampado.

Admirável plasticidade verbal a deste poema, feita de uma enorme economia de recursos, da disposição do silêncio, do implícito, da solidão e do vazio que esta arte da paisagem emocionalizada inventa.

A concentração sobre a reinvenção literária do Alentejo permite o surgimento de uma harmónica nova que se deixa ouvir nos poemas da segunda sequência, "Coro dos empregados da Câmara", "Tragédia", "Romance do terceiro-oficial de Finanças" e "Mataram a tuna!".

No primeiro poema ela conhece a sua formulação tópica:

É tão vazia a nossa vida,
é tão inútil a nossa vida
que a gente veste de escuro
como se andasse de luto. (p. 118)

Fechados na solidão, imobilizados pela rotina, assim cantam os membros de um coro masculino no qual quase insensivelmente uma voz se isola:

Ao menos se alguém morresse

e esse alguém fosse um de nós

e esse um de nós fosse eu... (118)

Não há razão gramatical alguma que impeça que nós ouçamos estes três versos pela voz de um só. Já é difícil supor o último verso dito por uma voz coral que entretanto poderia também cantar os dois primeiros.

Assim, estamos de novo perante uma oscilação ou uma hesitação ou falha que identifica numa voz colectiva, um sujeito individual. E de novo não é matéria de uma experiência psicológica mas apenas decorre da relação de uma forma sujeito com uma voz geral. 
Outro traço formal da enunciação de que podemos falar a partir deste poema é o que designarei como um paralelismo imperfeito, pelo qual o poeta vai falhando as regras da repetição paralelística que aparentemente vai prometendo.

O poema abre em pleno paralelismo sintáctico. O primeiro verso da $2^{\text {a }}$ estrofe - “...O Sol andando lá fora," - será repetido parcialmente no segundo verso da $3^{\mathrm{a}}$ (estrofe) - "e o vento andando lá fora". Os quatro versos finais da $2^{\mathrm{a}}$ estrofe serão repetidos na $3^{\mathrm{a}}$, mas com destinos diferentes: o último dos quatro será o primeiro da $3^{\mathrm{a}}$ estrofe e será ainda repetido como $10^{\circ}$ verso dessa estrofe, enquanto os outros três versos serão retomados como versos 7,8 e 9 dessa última estrofe.

Esta repetição de versos ou expressões sem haver intervalos regulares ou posições pré-definidas para a repetição é um dos traços estilísticos que caracterizam a arte poética de Manuel da Fonseca e, nomeadamente, marcam a desenvoltura e as liberdades que ele toma com as formas da tradição popular, de que se apropria.

A mesma imperfeição se regista na prosódia assumidamente oral desta poesia que, como outros mostraram, aceita o padrão métrico da redondilha maior, mas sem o cumprir de forma constante e vigiada.

O bloqueio ou o esvaziamento da energia e da pulsão de vida são a grande culpa de que é acusada a organização social deste universo.

Sem perspectivas de romper com o que se apresenta como um real intransponível, repetitivo e bloqueado, os humanos existem no plano degradado de uma existência em que a vida é curta e a morte infinita; daí que aqui possa ter lugar quer o susto com a passagem iminente da Senhora Dona Morte, quer o protesto contra a vida (corroída) que da vida (corrosiva) sobra. E contra esse bloqueio que se compreende que a Tuna do Zé Jacinto tocando a marcha Almadanim fosse algo de louco, e heróico e com o ser música não era música era raiva:

Mas tudo isso, que era tudo para nós,

Não era nada da vida!...

Da vida é isto que a Vida faz.

$\mathrm{Ah}$ ! Sim, isto que a vida faz!...

- Isto de tu seres a esposa série e triste

de um terceiro-oficial de finanças da Câmara Municipal!... (p. 123) 
No poema "Mataram a Tuna!":

$[\ldots]$

Meus companheiros antigos do bibe e do pião

agora empregados do comércio

desenrolando fazenda medindo chita

agora sentados

dobrados nas secretárias do comércio

cabeças pendidas jovens-velhinhos

escrevendo no Deve e Haver somando

na vila quieta

sem vida

sem nada

mais que o sossego das falas brandas...

$[\ldots]$ (p. 131)

No poema "Tragédia", a voz que diz o epitáfio do "senhor António", dispõe da escassez das suas palavras com uma ironia que range.

Em Manuel da Fonseca, a consolidação do modernismo é uma realização prosódica. Osvaldo Silvestre escreve sobre Manuel da Fonseca:

a sua poesia propor-se-á como oralidade dramática, pela qual a enunciação é delegada num vasto friso de personagens que assim conquistam finalmente a sua voz, no que é afinal uma reparação feita a todos aqueles a quem a História interditara a voz, relegando-os para a esfera do não-dito - e daí a oralidade desta poesia, tão devedora no tom e nas formas poéticas de tradições maioritariamente populares, isto é, não cultas. É esta, pois, uma poesia em que o realismo se declina em termos históricos e, sobretudo, materialistas, pela forma como se enraíza na concretude de personagens e situações. (SILVESTRE, 1996, p. 366)

Contra essa vida reduzida e bloqueada, ergue-se na paisagem do sol, sem sombra que não a que cai do céu, a figura múltipla do maltês, do vagabundo com as roupas rasgadas, do deserdado ou do degredado; do gitano da Andaluzia de Lorca, e como ele mais temível do que a morte, para as Nenas dos montes; do contador de coisas incríveis, tão incríveis que o próprio contador com elas se espanta.

Este carácter compósito da personagem do maltês implica um trabalho de decantação exercida sobre a demografia e a sociologia do Alentejo. Esse é em larga medida um trabalho da imaginação criadora. 
Não estou a insinuar que o maltês é uma invenção estritamente pessoal de Manuel da Fonseca e que não existem malteses no Alentejo. Estou apenas a dizer que enquanto personagem mítica e poética o maltês pressupõe um trabalho de Manuel da Fonseca que os poemas deixam ler nos seus traços míticos e nas cenas que formam o seu contexto de aparecimento. O maltês é um vagabundo ou um transumante que sinaliza as terras que atravessa como um lugar de desemprego sazonal e crónico, em que a atitude do latifúndio gera uma resposta, em que o desemprego parece ser uma iniciativa da vítima que, tomando-a, acusa desde sempre e para sempre, o latifundiário de não lhe ter deixado outra saída. O maltês representa um momento primeiro da consciência proletária, digamos: o momento anarquista. Por outro lado, figura do inconformismo e da insubmissão, o maltês toma-se de uma capa romântica: ele é a figura de um erotismo viril que perturba e ameaça as raparigas do monte, em "Estradas":

$[\ldots]$

Já estranhos rumores de folhas

entre as esteveiras andavam, quando, saindo um atalho, veio à estrada um vulto esguio.

Tremeram os seios de Nena sob o corpete justinho.

$[\ldots]$ (p. 115)

E essa dança prossegue:

Sob o corpete justinho uniram-se os seios de Nena.

$[\ldots]($ p. 110)

E pouco depois:

[...]

Já do corpete bordado

Os seios de Nena saíam

- como duas flores abertas

Por escuras mãos amparadas!

[...] (p. 116) 
Até que

$$
\begin{aligned}
& {[\ldots]} \\
& \text { Caiu-lhe da mão o saco } \\
& \text { junto ao atalho das silvas } \\
& \text { e sobre a sua cabeça } \\
& \text { o céu de estrelas se abriu! (p. 116) }
\end{aligned}
$$

"Para um poema a Florbela" é um dos mais longos poemas de Manuel da Fonseca. Tem 237 versos. É composto por X sequências, duas delas mono-estróficas, todas as outras compostas por 2, 3 e 4 subconjuntos de versos, separados por um branco maior. $\mathrm{O}$ carácter ondulatório e não linear do seu desenvolvimento exibem a cooperação entre o lírico, o narrativo e o dramático na poesia de Manuel da Fonseca.

Cada conjunto de estrofes, numerado em romano, é uma unidade de sentido, ora dominantemente lírico ora dominantemente narrativo. O procedimento a que chamei paralelismo imperfeito encontra aqui um excelente terreno de aplicação, quer no interior das X sequências, quer entre duas ou mais sequências.

Os acontecimentos que o poema figura realizam-se no território do Alentejo e, mais especificamente no território do maltês: - campos, campos, campos, abertos num sonho quieto que é, cruzamento de estradas e caminhos; um Alentejo que sofre uma deslocação no espaço, do Alto para o Baixo Alentejo e, na sua geografia humana, é uma terra bravia de fomes, com navalhas de malteses e coros de ganhões perdidos:

Caminhos do Alentejo

desde menino vos piso

no meu caminho pra Beja! (134)

Florbela move-se também:

$[\ldots]$

- quando a gente olha de longe

vê Florbela na torre alta,

esguia como quem era!

Que da torre alta de Beja

os olhos de Florbela, tão rasgados de lonjuras, vagueiam nos horizontes - como dois verdes faróis dos passos do meu caminho! 


\author{
Que a noite não é a noite \\ tombando na planície: \\ - é da torre alta de Beja \\ os cabelos de Florbela \\ destrançados sobre o mundo! \\ Que a manhã não é manhã \\ iluminando a charneca: \\ - é da torre alta de Beja \\ os olhos de Florbela \\ abrindo-se, devagar!... (p. 135)
}

Florbela é a beleza, a que fez poesia e a que soçobrou perante os da sua classe. E Ela é estranhamente também o outro de classe. Ela nunca mondou, nem ceifou, nunca colheu azeitonas " $[\mathrm{m}]$ as ela sabia tudo/ que há no coração da gente:/ - ouviu a gente cantar.” (p. 136). Florbela viveu exilada, na sua terra,

esbanjando braçados cheios

da grande vida que tinha! (p. 138)

Desce por vezes às casas ricas da vila ou às casas dos lavradores na cidade mas abandona vila e cidade porque "falava de tal maneira/ que ninguém a entendia” (p. 136) e porque ninguém a queria. [C]ansada/ de tanta vida dar,/ Florbela adormeceu antes da noite vir." (p. 140). Ergue-a a nossa boa mãe, a Senhora Dona Morte, e que alta e formosa fica Florbela. Ceifeiros, cavadores e malteses homenageiam-na.

\author{
$[\ldots]$ \\ e as moças dos montes \\ tremeram de espanto \\ como se na noite \\ um homem viesse \\ tocar-lhe nos peitos!... (p. 141)
}

Enfim a noite cai e cai com ela a calma sobre o corpo de quem, faminto, a procurou e não é essa calma a frescura da noite, mas

- é a mão de Florbela

tocando na minha fronte. (p. 144)

E por estranho que possa parecer é o gesto de Florbela que aqui consagra o poeta. 


\section{$* * *$}

Comunidade extensa e intensamente clivada entre malteses, ganhões e ladrões, porcariços e campaniços, ceifeiros, cavadores, moças dos montes e empregados de comércio, de um lado, e do outro, lavradores e senhores. Assim, o pequeno mundo que esta comunidade habita é uma pequena pátria onde inescapavelmente há que escolher um dos lados.

Lugar mítico (intensificado) de uma forma particularmente nítida e violenta de luta de classes, o Alentejo pode ser lido como a pequena pátria de Manuel da Fonseca.

A pequena pátria é o título de uma antologia [1971-2002] de João Miguel Fernandes Jorge. Sinalizo-o, não porque queira relacionar essas duas pequenas pátrias, diferentíssimas aliás, mas para pagar os direitos de precedência a João Miguel. Mas o que em pequena nota de abertura ele diz talvez interesse citá-lo aqui. "Os poemas nela (nesta antologia) incluídos têm uma intenção geográfica e histórica sem que sejam, de um modo necessário, paráfrases da geografia ou da história”.

A pequena pátria de Manuel da Fonseca é essa comunidade socialmente clivada que experimenta esse bloqueio e esvaziamento da vida e, por vezes, a repressão exercida pela lei que mora no cano das carabinas.

Uma pequena pátria é um bom antídoto quer contra a opressão do nacionalismo que só conhece a exclusão como modo de fundar a identidade, quer contra a dissolução das relações sociais num tal relativismo identitário que nos torna membros-súbditos de uma gigantesca Sociedade Anónima de Responsabilidade Limitada.

Da caracterização dessa pequena pátria nasce a imaginação de uma determinada pequena pátria outra; e a ética dessa comunidade que a habita dá a imaginar a ética de uma outra comunidade a vir. Não creio falhar muito a liberdade prosódica de Manuel da Fonseca se referir essa comunidade a uma terra sem amos.

\section{Mário Dionísio}

Se em Manuel da Fonseca a função testemunhal passa pelo carácter popular da enunciação poética, encontraremos outros poetas em que essa função se processa através da inscrição numa ou noutra tradição da poesia erudita. A poesia de Mário Dionísio testemunha rigorosamente 
de um tempo de urgência e paixão históricas e encontra vários tons de expressão dos afectos e da música elegíaca.

Em Mário Dionísio, o seu segundo livro de poemas, marca desde o seu título, Solicitações e emboscadas, 1945, uma percepção ao mesmo tempo inteligente e emocionalizada dos tempos que se vivem por alturas da data de edição desse livro. A ambivalência dos dois substantivos diz o caracter contraditório da esperança. Um poema como "Balada dos amigos separados" testemunha o universo dos afectos entre companheiros de clandestinidade, através da retomada do tema Ubi sunt da poesia da Idade Média latina, que se diria muito longínquo e reflectindo o universo de uma separação que consente em dizer-se num tom de lamentação amorosa, embora efectivamente se trate da separação a que a clandestinidade política obriga.

Onde estais vós Alberto Henrique

João Maria Pedro Ana?

Onde anda agora a vossa voz?

Que ruas escutam vossos passos?

Ao norte? ao sul? aonde? aonde?

José António Branca Rui

E tu Joana de olhos claros

E tu Francisco e tu Carlota

E tu Joaquim?

Que estradas colhem vosso olhar?

Onde anda agora a vossa vida repartida?

A oeste? A leste? Aonde? aonde?

Olho prà frente prà cidade

e pràs outras cidades por trás dela

onde se agitam outras gentes

que nunca ouviram vosso nome

e vejo em tudo a vossa cara

e oiço em tudo o som amigo

a voz de uma voz de outro

e aquele fio de sol que se agitava

sempre

em todos nós

Dançam as casas nesta noite

ébrias de sombra nesta noite

que se prolonga em plena angústia

aos solavancos do destino 
e não consegue estrangular-nos

Sigo e pergunto ao vento à rua

e a esta ânsia inviolável

que embebe o ar de calafrios

Onde estais vós? onde estais vós? (DIONÍSIO, 2016, p. 100-101)

A tradição que serve para viabilizar a enunciação testemunha do universo dos afectos que ligam entre si os militantes clandestinos surge, por exemplo, na "Elegia ao companheiro morto":

Meu companheiro morreu às cinco da manhã

Foi de noite ao fim da noite às cinco em ponto da manhã

Ah antes fosse noite noite apenas noite

sem a promessa da manhã

Ah apenas fosse noite noite noite apenas noite

e não houvesse em tudo a promessa risonha da manhã

$[\ldots]$

E era quase manhã E era quase manhã (DIONÍSIO, 2016, p. 103)

O poema de Mário Dionísio escreve-se sobre um poema de Garcia Lorca, Llanto por Ignacio Sánchez Mejías que é um conjunto de quatro elegias dedicadas a um amigo morto. O poeta português escolhe imitar a primeira dessas elegias, "La cogida y la muerte", usando no título o próprio nome do género, elegia. Elementos fundamentais dessa operação de transformação intertextual, são a transposição da dor privada da morte para a dor pela morte de um companheiro de luta e a alteração da hora em referência - A las cinco de la tarde. / Eran las cinco en punto de la tarde. - passamos, no poema em português para - Meu companheiro morreu às cinco da manhã / Foi de noite ao fim da noite às cinco em ponto da manhã. Esta alteração da hora traz para este poema as conotações codificadas nesta poesia do sonho da manhã, a promessa risonha da manhã. Esta hora da madrugada permite de forma discreta enfatizar o desperdício de uma vida que é roubada quando era quase manhã.

Para os detractores desta poesia é demasiado fácil esta transposição da morte privada em morte política, quando ela é sobretudo uma escolha rigorosa e a inscrição desta noite no fim da noite: 
meu companheiro ficou deitado para sempre

e com a boca cerrada para sempre

e com os olhos fechados para sempre

e com as mãos cruzadas para sempre

imóvel e calado para sempre

E era quase manhã E era quase manhã (DIONÍSIO, 2016, p. 103)

A nota introdutória ao livro Poemas (1936-1938), de 1941, que integra a colecção "Novo Cancioneiro" e onde se inclui a sequência $O$ homem sozinho na beira do cais, dá-nos a percepção aguda do tempo histórico da aventura poética desse autor:

Este livro é uma introdução à minha poesia e como tal deve ser considerado. Nele reúno os poemas feitos de 1936 a 1938 e que, constituindo embora uma fase já ultrapassada, suponho indispensáveis na concretização da longa marcha: do isolamento da beira do cais ao encontro e caminho com todos os homens nas estradas do mundo.

(DIONÍSIO, 2016, p. 24)

\section{Joaquim Namorado}

Como Fernando J. B. Martinho o notou, entre outros, o interesse dos neo-realistas por Fernando Pessoa longe de ser nulo, existe e é acentuado num livro como o Aviso à navegação (1941) de Joaquim Namorado. O interesse é marcado desde a epígrafe da primeira parte, "Navegação à vela" - "Pertenço a um género de portugueses que depois de estar a Índia descoberta ficaram sem trabalho" (NAMORADO, 1989, p. 173). Cesário Verde é citado como epígrafe da terceira parte deste livro "Arquitectura" - "Só sei desenho de compasso e esquadro." (NAMORADO, 1989, p. 197) - e como sabemos Cesário Verde é uma das referências tutelares da poesia de Álvaro de Campos. Para além disso, os poemas deste livro de Joaquim Namorado são claramente exercícios modernistas. Tematicamente a viagem marítima torna-se um tesouro de metáforas para a distância interna ao desejo:

deixa

que eu viva a aventura

sem bússolas e sem astros (p. 175) 
Ou:

Esta é a ilha perdida nos mapas, perdida no mar dos sargaços:

este é o mar das Tormentas, das tormentas desta vida, onde há só tempestades e agoiros; (p. 177)

“... o cais é uma saudade de pedra”, de Fernando Pessoa, é a epígrafe do poema "Cais".

E a tessitura dos versos, no poema "Noite calma dos portos", se evita a métrica e a rima, joga na assonância e na aliteração:

\section{$1 \quad 2 \quad 3$}

"Nas retinas mortas e roídas"

O poema "Manifesto à tripulação" é um caso exemplar de um verso livre que é submetido à distribuição numérica dos versos e das sílabas:

$4 \quad 5 \quad 4$

"O mar é fundo, as ondas são altas, o lenho é podre!" (p. 182)

$[\ldots]$

9

9

"Maior grandeza de sacrifício, maior força de nos excedermos, maior 9

4

sangue frio na manobra! E chegaremos...” (p. 183)

A repetição da estrutura sintática pode também evitar a liberdade completa do verso...

Se o nosso sacrifício de viver exige que sejamos vencedores, saibamos sê-lo com grandeza!

Se nos pedirem tributo, o tributo é o sangue!

Se nos pedirem preço, o preço é a vida! (p. 183)

Um poeta que se fascina com o desenho e as geometrias da poesia de Álvaro de Campos e do seu mestre Cesário Verde, chega naturalmente à percepção da "beleza nova dos maquinismos" (p. 202) do poema "Fábrica": 
$[\ldots]$

como se os metais fossem carne do corpo

e as veias se abrissem

àquela vida estranha, dura, implacável

das máquinas.

Os motores de tantos mil cavalos

alinhados e seguros de si,

seguros do seu poder;

as articulações subtis das bielas,

o enlace justo das engrenagens:

a fábrica, todo um imenso corpo de movimentos

concordantes, dependentes, necessários. (p. 202-203)

Essa vida estranha, dura, implacável das máquinas em "Dos condutores de máquinas":

Contacto:

os tempos do motor

transpiram a sua segurança de máquinas

- solda-se o braço no volante preso

e bate o coração no mesmo passo.

Olho estes homens condutores de máquinas

na simples ganga azul

do seu trabalho,

e é uma raça nova que nos meus olhos nasce

- nervos e eixos, êmbolos e eixos

são o mesmo aço. (p. 203)

ou em "África":

$[\ldots]$

batuques do Congo já não são de guerra!

Batuques de lanças quebradas:

batuques de guerra...não!

Nos cofres fortes do Cabo

o teu suor corre em libras...

- Yes, whisky and soda.

Nos cofres fortes do Cabo o teu suor corre em libras:

África da colonização! (p. 215) 


\title{
Carlos de Oliveira
}

\author{
Assim se movem \\ as nuvens comovidas \\ no anoitecer \\ dos grandes textos clássicos. \\ Carlos Oliveira, "Leitura", Pastoral.
}

Carlos de Oliveira é um poeta. Dois autores de personalidade intelectual tão diferente quanto Vitorino Nemésio e Mário Dionísio referiram-se-lhe através dessa palavra, poeta, mesmo quando a propósito dos seus romances. Poeta é aquele que constrói ou compõe um mundo de palavras e de possíveis verbais, com o qual, reconfigura, faz, desfaz, refaz e acrescenta o mundo de mundos que é o nosso. Fazer e compreender mundos são "jogos de linguagem". Mundo é um espaço - tempo com determinadas coordenadas e uma população com determinadas "formas de vida".

Carlos de Oliveira é um desses fazedores. E no entanto ele não se nos propõe sob a figura do demiurgo ou sequer do vate; antes por vezes sob a do artítice ou artesão. Mas de um artífice apaixonado, ou seja, afectado pela paixão, ou pelas paixões. Como em outros grandes, o seu ofício não é o de um labor aplicado, o de uma mecânica, óptica ou outra. As metáforas mais adequadas para o seu ofício poderão vir de outras físicas, da química ou da astronomia. Assim como a sua geometria (ou a sua retórica) já não é euclidiana, mas experimenta outras métricas com as quais o espaço se transforma e temporaliza e o sujeito aparece, resto e rastro, fóssil. O seu ofício transporta consigo uma paixão - o furor (paciente) de um desejo, a inquietação (tensa) de um fascínio, e o trabalho (obsessivo e rigoroso) de um mal.

Há na poesia portuguesa do século XX uma linhagem complexa e heterogénea que poderia designar como a da grandiloquência ou da exuberância discursiva e que reuniria por exemplo Teixeira de Pascoaes, Pessoa e em especial Pessoa-Campos, Jorge de Sena, Mário Cesariny e Herberto Helder. Carlos de Oliveira não vem nesta tradição, mas numa outra que poderíamos chamar a da veemência contida ou da contensão veemente. Com ela poderíamos relaccionar agora Pessanha, PessoaCaeiro e Pessoa-Reis, Ramos Rosa, Sophia e Eugénio de Andrade. Em relação aos que lhe são estritamente contemporâneos (por exemplo, 
Eugénio e Sophia), Carlos de Oliveira singulariza-se na medida em que a sua poesia não é a da transparência e da fusionalidade líricas, mas tende antes a ser a da opacidade da escrita e do seu fulgor exausto. A sua veemência é a da depuração que vibra. $\mathrm{O}$ trabalho da fulguração no extremo ou no limite.

A sua poesia conhece o pouco da linguagem, a sua imensa fragilidade ou labilidade, mas todo o rigor do inventor de jogos, que o poeta é, joga-se na busca da sua possível eficácia mínima. Da mesma forma, ele conhece as várias figuras que a noite encena, debate-se com as formas de um mal a que damos vários nomes, mas a sua obra não desiste de perscrutar essa noite (em busca, por exemplo, de uma estrela cuja luz nos chega ainda mas que pode estar já extinta), não deixa de falar e de esperar a fala. Essa resistência do espírito ao emparedamento é da ordem do histórico, do ético e do político. Como o é o facto de a sua obra trabalhar sinuosamente a conjunção de uma dor própria, pessoal, autobiográfica e de uma dor colectiva. Tal conjunção podemos tentar reconstitui-la à medida das dores que experimentamos ou temos por nossas. Ela é discreta, não fala demasiado alto.

\section{1.}

A obra de Carlos de Oliveira descobre e inventa antiquíssimas e novas questões: as da relação entre phýsis e lógos; entre o micro e o macro, o microscópico e o cósmico, entre a longa duração da evolução do Universo e a escala completamente outra da história humana, entre o espaço e o tempo, entre um desenho infantil e o cinema, entre o destino social e as condições histórico-sociais da individuação, entre a ficção autobiográfica e a rasura da confessionalidade. Esse trabalho é rigoroso, nem auto-complacente nem epigonal.

Carlos de Oliveira escreveu de várias formas sobre o rigor poético e sobre o trabalho oficinal. A crítica tem assumido essas fórmulas quando fala na sua obra. O que entendemos por esse rigor é um entendimento exigente da poesia como forma ou como trabalho formal na produção do(s) sentido(s) e como assunção ética desse trabalho. Trabalho de depuração, negatividade tensa, da decantação, rasura, elipse e fragmentação que vibram; minúcia da manipulação de pequenas massas sintácticas, produtividade sintáctica, prosódica, rítmica e semântica do uso do ponto e vírgula, discretos jogos consonânticos e vocálicos ("fogo, 
fulgor"); contensão da expressividade sentimental, modulação contida da emoção, da dor própria: pessoal e colectiva. Este trabalho é cumprido com a mais alta exigência de uma busca obsessiva e compulsiva da perfeição.

Carlos de Oliveira pertence a uma tradição que na modernidade é a da premeditação e a da autoconsciência do trabalho poiético da forma. Entretanto, esse trabalho não é praticado nem imaginado como um simples labor construtivo, mecânico ou mecanizável, todo método e cálculo. Esse trabalho inclui a preparação paciente de uma "pequenina explosão"; inclui a espera, a passividade disponível, o acontecimento imprevisível. Como o mostrou convincentemente Gustavo Rubim, esse trabalho "desfaz a oposição entre o cálculo e o acontecimento".

Há a este propósito uma longa tradição que pensa de forma dualista a poesia e as poéticas. Haveria num pólo o poeta voyant, inspirado, possuído ou órfico (a matriz está em Platão) e, num outro pólo, o poeta artiste, artífice, premeditado ou hermético (a matriz estaria agora em Aristóteles). De um lado, a inspiração, a força, a "chama", a energueia e, do outro, o cálculo, a forma, o "cristal", o ergon. A oposição não é de todo inverosímil, nem inútil, é possível vê-la como um particular sintoma da dificuldade de pensar uma identidade essencial e a-histórica do que seria a poesia. Mas Carlos de Oliveira é precisamente um daqueles que mostra como o dualismo rígido dessa bipolaridade pode deixar de funcionar: a sua obra é a de um artesão afectado pela paixão.

Na primeira fase, chamemos-lhe assim, da sua poesia, num poema em que a sua arte se emblematiza por versos de um outro, "Retrato do autor por Camilo Pessanha (colagem)", esse outro é justamente esse estranho poeta que julgaríamos pertencer à outra família.

Já na segunda fase, num livro que marca de maneira forte a mutação da sua poesia, Sobre o lado esquerdo (1968), encontramos uma outra "colagem" emblemática, que como tal se intitula:

Colagem

com versos de Desnos, Maiakovski e Rilke

Palavras, sereis apenas mitos semelhantes ao mirto dos mortos?

Sim, conheço 


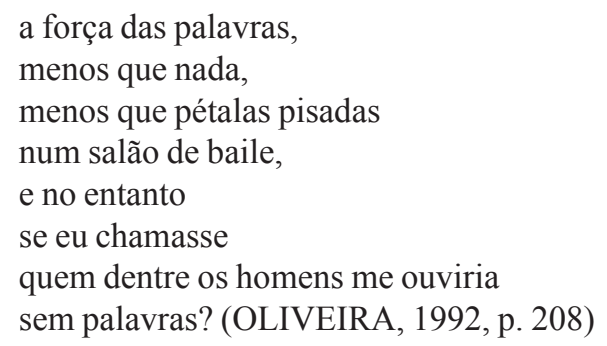

Os poetas citados, muito diferentes entre si, pertenceriam numa aplicação estrita da visão bipolar à linhagem dos visionários, mesmo se fortemente conscientes dos seus procedimentos de trabalho: um surrealista, um futurista e um pós-simbolista. Mas o fascínio por eles é uma das componentes na construção do poema, da poesia e da poética de Carlos de Oliveira.

O poema reúne pela mesma ordem em que os seus autores são enunciados no subtítulo do poema, citações mais ou menos transformadas. A primeira transformação é essa operação-acontecimento do encontro de frases e versos de três outros poetas, num poema de Carlos de Oliveira, com o tipo de estrutura e mancha gráfica que é a dos quase-sonetos que vêm de Cantata até Sobre o Lado Esquerdo e Micropaisagem.

Os quatro primeiros versos são a tradução, com pequenas modificações e a escansão em verso do fragmento $107^{\circ}$ de "Rrose Selavy" (1922-1923), incluído em Corps et biens (1930) (Mots, êtes-vous des mythes et pareils aux myrthes des morts?). Os seis versos seguintes vêm de esboços (1929-1930) de um poema de Maiakovski, só postumamente publicados (na trad. de Elsa Triolet: Je sais la force des mots. Moins que rien./ Moins que des pétales sous le talon d'une dame.). Dois versos transformam-se em seis, isolando por vezes uma só palavra e mesmo um monossílabo; a imagem final de Maiakovski é substituída por uma outra que como que a "desenvolve" no tempo e acentua o quase nada das palavras numa sugestão, acrescentada, de fim de festa. Finalmente, os últimos quatro versos vêm do incipit da "Primeira elegia de Duíno" (1923) de Rilke (Wer, ween ich schriee, hörte mich denn aus der Engel/ Ordnungen?) Um verso e a primeira palavra do segundo verso originam quatro versos sintacticamente opostos aos anteriores e com uma particular modificação semântica, por onde passa a diferença, Carlos de Oliveira. A tradução de Paulo Quintela - Quem se eu gritasse me ouviria dentre as ordens dos anjos? - permite observá-la. Os anos passaram a homens e o 
grito a chamamento. Não se trata de um banal e banalizador procedimento de des-sacralização. O leitor saberá que há anjos vários na poesia de Carlos de Oliveira, desde os do poema "Amazónia (V)" do seu primeiro livro, Turismo, até aos diferentes anjos de Entre duas Memórias (desde o "anjo camponês", que dá a ver a cena de "Descrição da Guerra em Guernica", aos anjos do poema "Salto em altura"). Carlos de Oliveira leu Rilke e terá tido o seu modo de entender do que falava Rilke com os seus anjos. Mas a transformação a que aqui procede não deixa de ser uma marca do carácter radicalmente terrestre do seu ethos poético e do seu rigor estratégico. Carácter esse que aqui se afirma também no chamamento. O chamamento é um gesto que antecipa o diálogo, um gesto que só se efectiva no horizonte já suposto do diálogo. E assim o podemos ler como atribuição indirecta à poesia disso que é uma função básica da linguagem, a do chamamento dos outros, a invocação e convocação dos humanos à sua condição de humanos. $\mathrm{O}$ canto do poema é então originariamente o canto da possibilidade de êxito desse chamamento, mesmo com o mais frágil, o mais lábil dos meios; mesmo na maior solidão. Canto discreto: o poema não diz sequer que chama com as suas palavras que são as palavras de outros; o poema limita-se a propor um condicional contrafactual: "se eu chamasse/ quem dentre os homens me ouviria/ sem palavras?"

\section{2.}

A sua obra é um mundo verbal, já o disse. Como tal, poderíamos reuni-la sob a invocação de títulos seus: Trabalho Poético (título sob o qual acolheu o estado final da sua poesia) e Finisterra (Paisagem e povoamento). Finisterra - terra extrema, terra do fim; Paisagem e Povoamento - o espaço e o tempo; o espaço temporalizado - o campo dos seus romances, o oco das colinas, os grãos das dunas, a estalactite e o jardim, as margens do rio em "Nas Colinas de António Machado" e em "Rio-despedida", de Cristal em Sória, são espaços marcados por uma ou outra (ou pelas duas) temporalidades: uma temporalidade geológica e cósmica, própria da cosmogonia, e a temporalidade humana, especificamente histórica e própria da construção antropológica. $\mathrm{O}$ tempo por sua vez investe o espaço, sedimenta-se, ou é uma linha de fuga, experimenta várias durações, deposita-se nos mapas e confunde ou mistura os traços mnésicos, gera uma cartografia transtornada e no labirinto desse mapa, a memória torna-se intransitável. 
Esta interacção entre espaço e tempo é caleidoscópica:

O espaço, mais do que uma paisagem imóvel ou um cenário é uma cena.

A própria paisagem é um processo ou um acontecimento ou uma estrutura de acontecimentos.

A paisagem é, mais do que um dado puro, uma construção cosmológica, tendencialmente cosmogónica. O local, o micro está em processo de ligação, desequilibrada ou assimétrica embora, com um cosmos.

Nenhum espaço é descrito sem que na sua descrição se inscreva ou marque o lugar ou o rastro de um sujeito que descreve e das suas operações. Esse sujeito não é uma mera superfície reflectora, alguém que assiste ao espectáculo do mundo, mas um agente envolvido e participante na reflexividade interminável da sua figuração.

A temporalização do espaço é uma condição da possibilidade de figurar os mapas como elementos de uma cartografia do tempo. Assim mapa é uma figura do poema enquanto organização verbal, espaço-tempo que miniaturiza um outro, lugar e condição possíveis de uma habitação a que somos convocados.

\author{
Mapa \\ I \\ O poeta \\ [o cartógrafo?] \\ observa \\ as suas \\ ilhas caligráficas \\ cercadas \\ por um mar \\ sem marés, \\ arquipélago \\ a que falta \\ $o$ vento, \\ fauna, flora, \\ e o hálito húmido \\ da espuma, \\ II \\ pensando \\ que
}




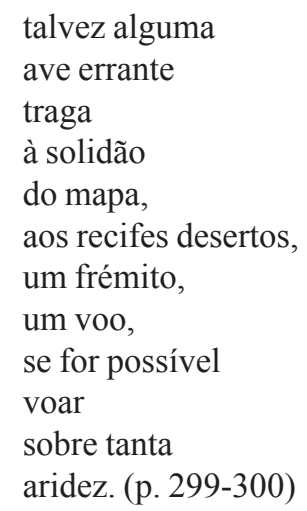

O povoamento é a relação de habitação com um espaço, por um lado pré-formado e, por outro ainda em formação (trans-formação) graças à sua dinâmica material e ao próprio povoamento. Ocupação ou travessia, casa ou transumância, como em Finisterra, o povoamento é o conjunto dos gestos de habitação: interiorização e apropriação subjectiva de um espaço e, ao mesmo tempo, objectivação do sujeito através do próprio processo de apropriação, processo no qual se constitui, se experimenta.

Fazer um mapa é, compreende-se, uma operação de habitação ao mesmo tempo real e imaginária. Fazer um mapa é uma acção em que a descoberta e a invenção se implicam; uma tarefa de representação e de inscrição. Enquanto actividades de habitação, os mapas multiplicamse, sobre-imprimem-se, tal como os gestos que os fazem e os desenhos protocolados ou convencionais que ostentam.

A habitação é também uma operação de rememoração e por isso no espaço do poema podem sobrepor-se vários espaços como em Entre duas memórias. Enquanto acção, no tempo, de rememoração e representação do espaço, o povoamento temporaliza a representação do espaço, mas ao mesmo tempo é obrigado a ceder, transitoriamente que seja, a formas de espacialização do tempo. Vimo-lo já em Cesário.

Um dos poemas de Entre duas memórias, "A segunda memória", figura-o: "a memória/ torna-se intransitável” (p. 364). E que se um mapa é o reconhecimento de um trajecto e uma busca de orientação, ele pode tornar-se, no limite, um labirinto. O mesmo poema diz também isso, logo no primeiro verso: "No labirinto deste mapa;" (p. 364). E virá a dizer o poema como uma cartografia transtornada. Entretanto, a poesia de Carlos de Oliveira é, justamente, mesmo nos momentos mais sombrios, 
a obstinada e rigorosa, mesmo se desesperada, tentativa de construir mapas do labirinto e da memória intransitável. Assim como de fixar um retrato que ameaça decompor-se.

Resultante deste cruzamento entre tempo e espaço e do modo como essas coordenadas são tomadas como atributos da própria realidade do poema - escultura e música no espaço-tempo da página e da leitura, gera-se uma intensa reversibilidade entre os planos desta poesia: a representação da paisagem através de um sistema de marcas que inscrevem numa superfície plana a rugosidade concreta de um território, a mostração e a figuração do poema; a contrução subjectiva e a cintilação da história colectiva; a cartografia e a leitura.

\section{3.}

Uma parte pelo menos da singularidade da poesia de Carlos de Oliveira vem da articulação de dois movimentos, um de representação, o outro de mostração auto-reflexiva, ou por outras palavras, um de suposição e de desejo insistente do real, e o da figuração das formas operatórias desse desejo, o da inscrição dos gestos caligráficos que produzem cenas e mapas. Combinando esses dois movimentos, a poesia de Carlos de Oliveira torna-se representação da representação, metarepresentação que ausculta a sua eficácia e a sua impossibilidade, que regista os seus fracassos e a compulsão que a leva a insistir. Dito de outro modo: trata-se de uma das obras poéticas em Portugal onde é mais frequente e intensa a figuração da poesia, do fazer-se e do funcionamento do poema, pelo próprio poema.

Assim, a poesia de Carlos de Oliveira reúne dois movimentos que encontramos disjuntos em alguns momentos e poéticas contemporâneas. A sua poesia pode ser designada como uma poesia da poesia. E entretanto de uma maneira particularmente intensa a poesia mostra-se como um desejo de mundo no próprio momento em que se figura como desejo de palavras. Daí que a figuração da poesia não seja aqui um modismo repetitivo e improdutivo. Este duplo movimento e desejo é antes, segundo creio, o gesto característico que corresponde a uma inquietação central e constitutiva. Aqui a pulsão auto-referencial desregula a especularidade narcísica, não se apresenta como ensimesmamento e enfraquecimento do desejo de real, é uma condição de possibilidade da afirmação desse desejo e corresponde a uma necessidade de buscar, construir e afirmar 
a sua poética num campo que dificulta a compreensão da sua específica singularidade. A obsessiva auto-referencialidade da sua poesia, é em Carlos de Oliveira, como em Francis Ponge, Jorge Guillén, ou João Cabral de Melo Neto, um gesto de consciência artística, a intencionalidade da produção (poíein) de um objecto ideal, que é um novo existente real, e o espaço de afirmação de um desejo de mundo e de real.

Por um lado, o poema apresenta-se como um mundo, miniatura de um mundo, um mundo verbal que se pode auto-referir usando as palavras que na língua comum são habitualmente usadas para referir o mundo físico. Não sendo um daqueles que acreditam na fusão analógica entre palavras e coisas, a sua poesia busca entretanto uma circulação e uma contaminação entre as palavras que referem o mundo do poema (do discurso e do pensamento), e aquelas que referem a phýsis, o mundo físico.

Por outro o lado, esse mundo verbal é uma espécie de modelo ou de versão que simula o mundo de mundos a que chamo o real. Como o são, em Finisterra, um desenho infantil, uma pirogravura, uma fotografia, um filme, uma maqueta, um mapa mental, etc.

E, terceiro aspecto, o poema imagina-se como parte do mundo que o contém e nos contém a nós e, nessa condição, se nos propõe a nós seus leitores e habitantes históricos.

Tarde (de Sobre o lado esquerdo, p. 206)

A tarde trabalhava

A

sem rumor

no âmbito feliz das suas nuvens,

conjugava

A

cintilações e frémitos,

rimava

A

as ténues vibrações

do mundo

quando vi

B

o poema organizado nas alturas

C

reflectir-se aqui,

B

em ritmos, desenhos, estruturas

C

duma sintaxe que produz

D

coisas aéreas como o vento e a luz

D 
Dotado o mundo de uma gramática (conjugava e rimava) e de um léxico (cintilações e frémitos) e o poema de ritmos, desenhos e estruturas, a reverberação entre os dois leva a que a sintaxe do poema reflicta o poema do mundo (o poema organizado nas alturas e produza coisas aéreas como o vento e a luz. O poema faz aquilo que diz e mostra a reverberação imperfeita na imperfeição do seu esquema rimático que só se regulariza nos últimos seis versos (nos tercetos do quase soneto), precisamente os versos que dizem a reverberação entre os mundos.

Em Carlos de Oliveira, manifesta-se de maneira complexa e vibrante um tipo de imaginação particularmente denegada - a imaginação materialista - aquela que supõe uma imaginação da matéria ou do mundo material, que em nós ecoa, na imaginação poiética que com ela busca cumpliciar-se, ou na poesia e na arte que buscam simulá-la. Na nossa civilização, essa imaginação vem-nos desde os pré-socráticos, passa pelo admirável poema de Lucrécio, onde átomos e letras, corpos e palavras se tornam figuras solidárias e reenviam através dos ares os seus simulacros, e vem por exemplo até à frase de Picasso - Não se trata de imitar a natureza, mas de trabalhar como ela.

A necessidade de unir concretamente (ou seja, dando espaço ao processo da contradição) entre a figuração do mundo e figuração do poema não se deve apenas à argumentação da poesia como forma do conhecimento artístico; vem também de que a poesia é também em Carlos de Oliveira uma "forma de vida".

O que se joga então na sua obra, de forma admirável e comovente, não é apenas o desejo de conhecimento, mas aquilo que me atreverei a designar como uma espécie de consciência da necessidade de defender, de proteger, de salvar o real, tentando usar esta última expressão sem qualquer dimensão religiosa ou salvífica. É como se o real se estivesse a degradar; a funcionar mal no espírito dos homens, a tornar-se inabitável, varrido "pela tempestade das coisas desencadeadas", a perder-se porque vamos morrer ou porque perdemos os mapas e já não conseguimos cartografar. Francis Ponge diz a certa altura, num texto dos anos 50, que o mundo está a funcionar mal e que o poeta, $\mathrm{o}$ artista tem a responsabilidade, a tarefa de o reparar na sua oficina, de o reparar no sentido em que se reparam máquinas ou automóveis, peças ou bocados de mundo. Precisamente, salvar o real é também uma maneira de resistir ao que ameaça de irrealidade o sujeito. É em suma não apenas uma tarefa ontognosiológica, mas também ética e política. Uma tarefa poética e vital. 
Este intenso compromisso com o real marca toda a obra de Carlos de Oliveira. Entretanto, ele sabia que o poema pode criar um real não existente, um inexistente que desrealiza a realidade

Ouçamos o poema "Nevoeiro" (p. 225), mais uma vez desse admirável livro que é Sobre o lado esquerdo:

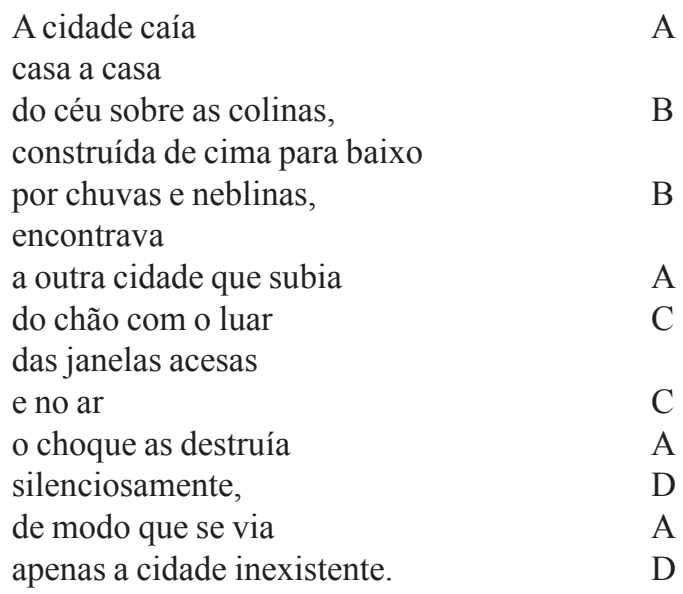

No poema, alguém olha de uma janela uma cidade, de noite, à chuva. O seu olhar vê aquilo que vê, deformado por "chuva e neblinas" e pelo "luar/ das janelas acesas". O poema constrói a cidade inexistente seguindo primeiro um olhar descendente e depois um outro, ascendente. De cima para baixo, a cidade cai, e de baixo para cima a outra cidade sobe (ou cresce); e no ponto ou na zona da janela (suposta) em que os dois olhares se encontram e lá fora, as duas cidades chocam e se destroem, o que é dado a ver nessa destruição é "a cidade inexistente". É preciso aceitar que poemas dão a ver, para depois podermos dizer que este poema pratica para nós uma alucinação. O que é particularmente curioso é que ela é conseguida respeitando o poema a nossa experiência perceptiva. Nas condições que o poema vai indicando, é inteiramente verosímil, ou seja, aqui, possível ver apenas a cidade inexistente. Por isso mesmo, esta alucinação não pode ser entendida como uma percepção sem objecto. O objecto está lá, a percepção e o poema que renova a sua experiência, apenas a transfigura. Estamos perante a alucinação poética de que Rimbaud escreveu e que é um meio fundamental da poesia da modernidade, pelo menos. 
A cidade inexistente é uma ficção da percepção que é nela verdadeira. A desrealização do real pode ser assim um meio de o libertar de uma rotina embotada e estéril, e de abrir no seu coração o espaço do possível. Que ele contém. A possibilidade do poema e da imagem. A possibilidade da vida ressurrecta.

Assim acontece no último momento de "Descrição da Guerra em Guernica":

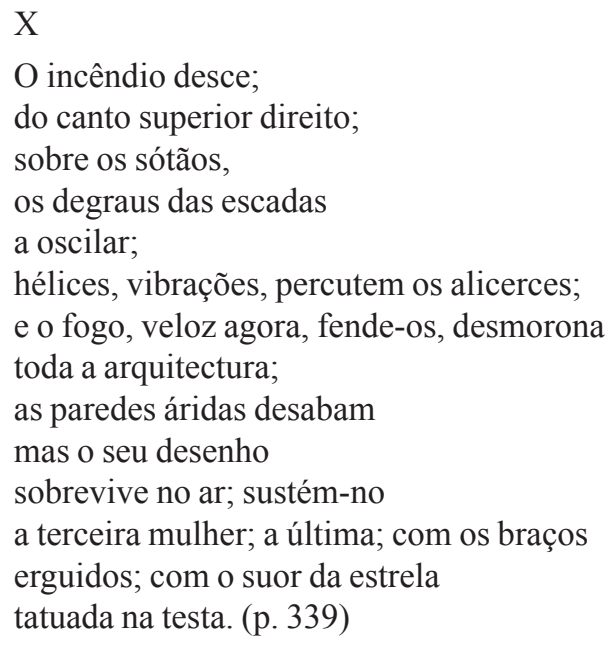

Neste último momento da descrição fortemente modalizada da pintura de Picasso, que o poema pode dar a ver, porque num primeiro momento, "o anjo camponês" "entra pela janela " "com a terceira luz na mão", sob o bombardeamento tudo o que estava construído se desmorona e desaba. Mas o poema identifica na pintura, uma mulher (a terceira, uma vez que já contou duas outras), a quem marca e a quem atribui o papel ou a função de suster, de fazer sobreviver, no ar, o que da destruição ficou, o desenho, ideal, das paredes Mas trata-se de uma espécie de memória imaterial que resta da desmaterialização das casas e das suas paredes ou de memória da arquitectura, o desenho é o desenho de quem as projectou. A sobrevivência no ar transforma-se assim num gesto duplo, é em qualquer caso esse gesto duplo, o do testemunho e o da promessa da reconstrução, o gesto antropológico da poesia: o gesto que a poesia descobre e inventa na linguagem. 


\section{4.}

Deve compreender-se que esse rigor de que tanto falamos a propósito de Carlos de Oliveira é uma qualidade da imaginação verbal que, num quadro histórico de várias tradições e "famílias", inventa as suas regras. É assim o rigor do voo da imaginação. Só que esse voo conhece a gravidade e, por isso, ao contrário dos anjos que a não conhecem, pode sofrer as leis reais do nosso peso, e pode, por isso, conhecer-nos.

Esta procura do rigor é legível em cada texto, na sua organização interna, no modo como os versos se escandem, na selecção e constelação das palavras que fulgem, no modo como caligraficamente se desenham as imagens que renovam a percepção. É legível na organização dos livros e também no trabalho singular, mesmo se não o único, na nossa literatura, de reescrita intensa dos seus livros (poesia e romance). Assim, a sua obra vive num movimento duplo que se transforma em triplo, como bem o viu Rosa Maria Martelo. Por um lado, o movimento cronológico das primeiras edições de cada livro, por outro, o gesto da reunião e da reescrita em Poesias (1962) e Trabalho poético (1976), que nos dará o estado final da sua obra. Mas da combinação destes dois movimentos, surge inescapavelmente um terceiro: aquele que estuda o modo e o tempo da reescrita, - o modo como os livros mais tardios reescrevem os livros que os antecederam e como esse trabalho do fim sobre o princípio, do futuro sobre o passado não apaga a diferença dos tempos, não nos instala num presente sem tempo, antes nos remete, para a pluralidade do tempo histórico, cronologia, anacronismo, travessia dos tempos e interrupção do devir como emergência do tempo messiânico.

A reescrita que conduz à instância final da obra é o modo de Carlos de Oliveira experimentar o dinamismo da escrita que infinitiza o finito. Ela exibe-se de duas maneiras fundamentais: dando a ler na obra final, in praesentia, a retomada e a variação de temas e motivos; permitindo (se não obrigando a) ler, in absentia, sob a versão final ou as versões anteriores, o texto rasurado.

Lereis o poema "Oiro", que conheceu a sua primeira edição em Cantata (1960). Manteve-se inalterado em Poesias (1962), mas em Trabalho poético os três versos finais são modificados. A versão final será assim: 


\author{
O dia acende \\ o teu olhar \\ e não te deixa \\ adormecer \\ sem que essa luz \\ seja cravada \\ pelo punhal do sol \\ na eternidade, \\ halo breve \\ e doirado \\ como o poema. (p. 195)
}

Na sua primeira versão o poema terminava assim

\author{
coisa breve \\ e doirada \\ como a vida. (OLIVEIRA, 1962, p. 164)
}

Compreende-se a substituição. Por um lado, o poeta evita um jogo sobre um tópico muito generalizado: o da brevidade da vida; assim como evita uma redundância inerte entre a luz que acende o olhar e a vida. E por outro lado multiplica as relações de sentido. O que é agora relacionado é essa luz acesa, no olhar e o poema através da imagem do halo que dele emana. Assim como a brevidade e a evanescência do poema se confrontam com a ausência de limites temporais da eternidade. A substituição de "coisa" por "halo" sugere que o poema é uma espécie de anel de luz que coroa uma qualquer coisa, no momento em que ela se desmaterializa, ou uma propriedade de um olhar aceso e vigilante que banha essa coisa num outro ambiente perceptivo. Cravado na eternidade pelo punhal do sol o poema que é uma breve vibração luminosa, um rápido fulgor, uma cintilação, pretende ao sem tempo.

Mas reparem, como leitores que conhecem as duas versões, não podemos esquecer totalmente a primeira versão, justamente preterida. Podemos e devemos rasurá-la; mantê-la rasurada; mas podemos lê-la sob a rasura e ler no texto final o gesto da rasura e o texto rasurado. E então a passagem de uma versão a outra é algo que se acrescenta à leitura desta:

O poema é um halo, a aura de uma coisa ... que é da vida, ou é vida e como ela breve e doirado. Mas como halo, como vibração intensa e fugaz da luz pode talvez sobreviver; o poema é uma espécie de vida sobreviva e restante. Dito de outro modo: O poema substitui por halo a 
coisa - vida, mas a substituição da palavra "vida" pela palavra "poema", no poema, parece deixar imaginar uma relação entre uma coisa e outra, uma relação que só pode existir nesse seu apagamento - mas que é a relação que as tornou substituíveis uma por outra na reescrita. Rasurada, incomensurável com o poema, a vida é algo que está naquele texto que está sob este texto final.

\section{5.}

Os dois últimos livros publicados por Carlos de Oliveira mostram a outra luz e noutra dimensão este trabalho de reescrita.

A obra de Carlos de Oliveira começara em 1942, com o livro de poemas Turismo e, em 1943, com o romance Casa na duna. O alinhamento à chegada inverte-se: é de poesia o penúltimo livro - sai em 1976 a primeira edição de Trabalho poético, que incluía a colectânea inédita, que terá edição autónoma no ano seguinte (1977). Em 1978, sai a primeira edição de Finisterra, romance, um dos mais belos textos em prosa do séc. XX em Portugal.

Finisterra, último romance reescreve os romances anteriores e especialmente o primeiro, Casa na duna. O subtítulo, Paisagem e Povoamento é uma espécie de condensação temática da organização interna de "Turismo" em Trabalho poético: "Infância" / "Amazónia" /"Gândara". Mas sobretudo pode dizer-se que é a poesia que fora escrevendo depois de 1956 e que o levara a reescrever os livros de poemas até Cantata, que comanda a reescrita dos romances e neste caso de Casa na duna. Vindos de vários lugares da sua obra vêm motivos e temas, as obsessões reúnem-se, de forma inapagavelmente outra em Finisterra, e produzem esse estranho romance: a história do desaparecimento de uma casa familiar; ruína e fantasmas de infecundidade e morte; a pobreza e a transumância dos camponeses que o tatuou desde a infância, a geografia e a arqueologia geológica da região da Gândara entre o real, o simbólico e o imaginário, entre o real e o mítico; a impossibilidade do nascimento; as diferentes formas, meios e procedimentos, assim como as dificuldades da representação, suscitação e transformação do mundo e da vida, a tentação da cosmologia, o fascínio pela noite sideral e a maquinaria celeste.

Pastoral, último livro de poemas, penúltimo título da obra é uma pequena colectânea de 10 belíssimos poemetos que, de certa forma, como que recapitula e resume intensamente alguns dos dramas fundamentais 
da sua poesia. Os poemas em posição extrema, o poema liminar, "Registo", e o poema que termina o livro, "Musgo", encenam de forma crepuscular uma despedida do mundo que é também indissociavelmente uma despedida da poesia. Se a poesia é um "registo", ela envolve um desejo de conhecimento - "Saber que seja / este hálito: se terra / ou ar movido" (p.389) - mas o poema diz as dificuldades da representação: o "ter desenhado o horizonte/ com o seu traço/ mais volátil" leva a "vermos só/ a tinta evaporar-se" (p.389). O poema diz que não há outro registo; não há outras possibilidades de representação mas apenas alíneas deste registo, que flutua como flutuam os elementos da paisagem, as colinas, a cal ainda tensa das casas, tudo à beira do apagamento total pelo crepúsculo esponjoso assim como se evapora a tinta que desenhou o horizonte. As três estrofes do poema "Musgo" iniciam-se por um gesto que ao mesmo tempo, adia e antecipa o fim - Dir-se-á mais tarde; // Dir-se-á depois // Dir-se-á por fim / que nenhum tempo se demora / na rosácea intacta; e da representação o que restará então é a inscrição do musgo na pedra; uma vez "que só o musgo dá;/ em seu discurso esquivo / de água e indiferença; / alguma ideia disto" (p. 408). Para onde se aponta com o deíctico, isto? Coisa pobre da paisagem desolada, o musgo talvez possa estar por isto, inscrição a que se reduz o poema enquanto cena da representação e do mundo nessa cena.

Entre estes dois poemas, todos os outros retomam temas e motivos que vêm da sua poesia anterior, repetem e variam essa cena da representação exausta de um mundo que é um vale glaciar, uma variante do deserto inicial, uma montanha ou colinas; água e pedra, nuvens e ar, fogo e fogo que arde sem se ver, metamorfoses e trocas materiais; um mundo que vai entrar no crepúsculo, que absorve camponeses, pastores e rebanhos, e em que as luzes urbanas fazem explodir estes sonhos.

E contudo, mesmo na maior desolação, resultante de um processo material, eis minuciosamente, halo imaterial do mundo, a beleza:

\author{
E levanta-se então. \\ Minuciosamente. Ergueu-se \\ o halo \\ das colinas; a lenta beleza \\ levitada em cada grão \\ de pedra. [...]
}




\section{$* * *$}

Julgo que devo ainda insistir: Carlos de Oliveira é um dos maiores poetas do séc XX em Portugal. Repito-o agora já em outro século, com o mesmo sentimento de urgência com que o tenho dito já em outras ocasiões. Só a desatenção e o preconceito, "as coisas desencadeadas" e um modo de guerra ao lidar com a poesia podem impedir que este juízo seja um lugar comum que se abre aos nossos encontros. Digo-o no tempo e contra o tempo, procurando "evitar que a tempestade das coisas desencadeadas nos corrompa ou destrua". Articular historicamente este (meu) passado, vir aqui falar em favor de Carlos de Oliveira escolhendo a sua poesia é ir ao encontro do encontro com a sua fulguração, no instante do perigo.

A poesia de Carlos de Oliveira é daquelas que nos obriga a encontrar uma maneira de usar uma palavra que ela própria usa, mas que caiu em desuso: a palavra beleza. Com os seus poemas, fazemos frequentemente a experiência daquilo a que chamávamos a beleza. Que fulmina como um relâmpago, queima como uma ponta de gelo ou é já só um brilho restante à beira da exaustão, o fulgor do halo de uma coisa que vai extinguir-se. É talvez uma palavra que ao mesmo tempo esconde outras e a elas se entreabre. É talvez uma catacrese, uma palavra que pretende impropriamente designar algo para o que não há nome próprio na língua.

Nesta poesia, há fórmulas ou formulações, imagens e ritmos, acontecimentos prosódicos, figuras da linguagem e do mundo que nos co-movem; sem o que viveríamos de outra maneira; mais pobre. Isso acontece mais frequentemente com os grandes poetas.

\section{Referências}

BENJAMIN, W. Sobre o conceito da História. In: . O Anjo da História. Edição e tradução de João Barrento. Lisboa: Assírio \& Alvim, 2010. p. 9-20.

DIONÍSIO, M. Poesia completa. Lisboa: Imprensa Nacional-Casa da Moeda, 2016.

FONSECA, M. Obra poética. 7. ed. revista pelo autor. Pref. Mário Dionísio. Lisboa: Caminho, 1984. 
NAMORADO, J. Aviso à navegação. In: TORRES, A. P. (Pref., Org. e Notas). Novo Cancioneiro. Lisboa: Caminho, 1989. p. 169-215.

OLIVEIRA, C. de. Poesias:1945-1960. Lisboa: Portugália, 1962.

OLIVEIRA, C. de. Obras. Lisboa: Caminho, 1992.

REDOL, A. Gaibéus. 18. ed. Pref. Óscar Lopes. Lisboa: Caminho, 1993.

ROSAS, F. O Estado Novo 1926-1974. História de Portugal. Dir. José Mattoso. Lisboa: Círculo de Leitores, 1994. v. 7.

SILVESTRE, O. Manuel Dias da Fonseca. In: ROSAS, F.; BRITO, J. M. B. de (Dir.). Dicionário de História do Estado Novo. Lisboa: Círculo de Leitores, 1996. v. I, p. 366-367. 
